\title{
Evaluasi Status Degradasi Lahan Dataran Tinggi Akibat Produksi Biomasa Di Kabupaten Probolinggo, Jawa Timur
}

\author{
Evaluation on Highland Damage Status due to Biomass Production in Probolinggo, East Java \\ Purwadi $^{1 *}$ dan Siswanto ${ }^{1}$ \\ ${ }^{1}$ Program Studi Agroteknologi, Fakultas Pertanian, UPN "Veteran” Jawa Timur, Indonesia \\ *Email korespondensi: purwadi@upnjatim.ac.id
}

Diterima: 09 September 2019 / Disetujui: 13 Januari 2020

\begin{abstract}
Based on preliminary information from the Probolinggo District Environmental Agency (BLH), Its has experienced degradation due to land conversion, steep land use and inappropriate land use, which causes erosion, sedimentation and silting of rivers. It causes flooding and degradation of soil fertility, critical land, which in turn decreases agricultural production and reduces farmers' incomes. This study aims to evaluate the status of land damage due to biomass production in the highlands, which includes seven districts namely Gading, Tiris, Kuripan, Krucil, Sukapura, Lumbang and Sumber. This research is a case study, based on a semi-detailed scale survey with a ratio of 1:50,000. Soil sampling locations, selected based on overlay or superimpose on several thematic maps. Research data collected are (1) Identification of initial soil conditions, which is carry out through an inventory of secondary data or primary data (2) Analysis of basic soil properties (3) Land use related to land cover (4) Evaluation of the status of soil damage. The conclusion of the study, the status of soil loss is clasified as slightly damaged including Tiris and Kuripan sub-districts with limiting factors: composition of sand and colloid fraction (f), permeability, and redox (r). Meanwhile, those classified as damaged include sub-districts: Sumber, Sukapura, Lumbang, Krucil, and Gading. Limiting factors: composition of sand and colloid fractions (f), (b), fill weight (b), total porosity (v).
\end{abstract}

Keywords: biomass, critical land, degradation, highland

\section{ABSTRAK}

Berdasarkan informasi awal dari Balai Lingkungan Hidup (BLH) kabupaten Probolinggo, di wilayah tersebut telah mengalami degradasi lahan karena alih fungsi dari lahan, penggunaan lahan yang curam dan tata guna lahan yang kurang tepat, menyebabkan erosi, sedimentasi dan pendangkalan sungai. Hal tersebut menyebabkan banjir serta degradasi kesuburan tanah, lahan menjadi kritis, akhirnya produksi pertanian menurun dan mengurangi pendapatan petani. Penelitian ini bertujuan untuk melakukan evaluasi status degradasi lahan akibat produksi biomasa sebagai akibat alih fungsi lahan dari penggunaan lahan berupa hutan menjadi budidaya tanaman secara intensif. Lokasi penelitian di wilayah dataran tinggi meliputi kecamatan: Gading, Tiris, Kuripan, Krucil, Sukapura, Lumbang dan Sumber. Metode penelitian menggunakan studi kasus, sebagai obyek lahan berdasarkan survey skala semi detail dengan perbandingan 1:50.000. Lokasi pengambilan sampel tanah dipilih berdasarkan overlay beberapa peta tematik guna memperoleh gambaran tentang areal yang berpotensi mengalami kerusakan lahan. Pengambilan data meliputi: (1) Identifikasi kondisi awal tanah dilakukan melalui inventarisasi data sekunder dan/atau data primer (2) Analisa sifat-sifat dasar tanah, di laboratorium meliputi sifat fisik, kimia dan biologi tanah, (3) Penggunaan lahan terkait dengan penutupan lahan, (4) Evaluasi status kerusakan tanah. Kesimpulan dari penelitian, status kerusan tanah tergolong rusak ringan meliputi kecamatan Tiris dan Kuripan dengan faktor pembatas: komposisi fraksi pasir dan koloid (f), permeabilitas, dan redoks (r). Sedangkan yang tergolong rusak sedang meliputi kecamatan: Sumber, Sukapura, Lumbang, Krucil, dan Gading. Faktor pembatas: komposisi fraksi pasir dan koloid (f), (b), berat isi (b), porositas total (v).

Kata kunci: biomasa, degradasi, lahan kritis

\section{PENDAHULUAN}

Kabupaten Probolinggo terletak di lereng pegunungan yang membujur dari Barat ke Timur, yaitu Gunung Semeru, Argopuro, Lamongan dan Tengger. Selain itu terdapat gunung lainnya, yaitu Gunung Bromo, Widodaren, Gilap, Gambir, Jombang, Cemoro Lawang, Malang dan Batujajar. Potensi terjadinya degradasi lahan khususnya di wilayah dataran tinggi kabupaten Probolinggo disebabkan beberapa hal yaitu: erosi, pencemaran akibat proses pertanian, deforestasi, overgrazing, ladang berpindah, dan pertanian monokultur.

Berdasarkan informasi awal dari Balai Lingkungan Hidup (BLH) Kabupaten Probolinggo tahun 2018, lahan di wilayah dataran tinggi kabupaten Probolinggo menunjukkan tanda-tanda mengalami degradasi lahan. Apabila tidak segera dilakukan pencegahan untuk mengatasi degradasi lahan 
secara cepat dan tepat, dikhawatirkan akan menjadi lahan yang kritis.

Lahan kritis dapat juga diartikan sebagai suatu lahan yang keadaan fisiknya sedemikian rupa sehingga lahan tersebut tidak dapat berfungsi secara baik sesuai dengan peruntukannya sebagai media produksi ataupun media tatanan air (Menteri Kehutanan, 2001). Sedangkan menurut Zain, 1998, pengertian lahan kritis adalah lahan yang tidak mampu secara efektif digunakan untuk lahan pertanian, sebagai media pengatur tata air, maupun sebagai pelindung alam lingkungan. Dapat juga didefinisikan sebagai lahan yang tidak sesuai antara kemampuan tanah dan penggunaannya akibat kerusakan secara fisik, kimia, dan biologis sehingga membahayakan fungsi hidrologis, sosialekonomi, produksi pertanian ataupun bagi pemukiman. Hal ini dapat menimbulkan bencana erosi dan longsor di daerah hulu serta terjadi sedimentasi dan banjir di daerah hilir (Zein, 1998).

Melalui Parameter Tanah Untuk di Lahan kering sebagaimana ketentuan Peraturan Menteri Lingkungan Hidup Nomor 7 Tahun 2006 tentang tentang Tata Cara Pengukuran Kriteria Baku Kerusakan Tanah untuk Produksi Biomassa, yang meliputi sifat fisik, kimia dan biologi tanah, yaitu : Erosi, Ketebalan Solum, Kebatuan Permukaan, Komposisi Fraksi, Berat Isi, Porositas Total, Derajat Pelulusan Air, pH Tanah, Daya Hantar Listrik, Nilai Redoks, Jumlah Mikroba Tanah.

Tujuan pelaksanaan kegiatan adalah untuk mengetahui status kerusakan lahan dan penyebaran lahan kritis akibat produksi biomasa di wilayah dataran tinggi Kabupaten Probolinggo berdasarkan kajian kriteria baku kerusakan tanah.

\section{BAHAN DAN METODE}

\section{Lokasi dan Waktu Penelitian}

Lokasi Penelitian berada di lahan dataran tinggi yang tersebar di 7 (tujuh) Kecamatan dengan titik pengamatan di setiap kecamatan : (a) Sukapura dengan ketinggian $921 \mathrm{dpl}$ (b) Gading dengan ketinggian $756 \mathrm{dpl}$, (c) Tiris dengan ketinggian 925 dpl, (d), Kuripan, dengan ketinggian 789 dpl, (e), Krucil dengan ketinggian $936 \mathrm{dpl}$, (e) Lumbang dengan ketinggian 774 dpl, dan (f) Sumber dengan ketingian 832 dpl. Penelitian ini dilakukan mulai Mei - Juli 2019.

\section{Data Penelitian}

Data yang digunakan dalam penelitian ini adalah data pengukuran dan observasi lapangan pendugaan produksi biomasa di setiap kecamatan, peta tutupan lahan, peta tanah, peta penggunaan lahan dan peta kelas lereng, serta data kondisi umum di lokasi penelitian. Hasil dari Overlay peta tersebut,diperoleh satuan lahan yang yang merupakan titik pengamatan pengambilan sampel data biofisik, disamping itu juga di cocokkan di lapangan dengan menggunakan Global Positioning System (GPS).

\section{Metode Penelitian}

Tahapan penelitian mulai dari pengolahan peta, pengumpulan data di dilapangan berdasarkan karakteristik lahan (table 1), analisisa contoh tanah di laboratorium, dan penilaian kekritisan lahan dilakukan berdasarkan Peraturan Menteri Lingkungan Hidup Nomor 7 Tahun 2006 tentang Tata Cara Pengukuran Kriteria Baku Kerusakan Tanah untuk Produksi Biomassa, yang meliputi sifat fisik, kimia dan biologi tanah untuk lahan kering, tersaji dalam table 2 .

\section{Penyusunan Status Kerusakan Tanah}

Tahapan selanjutnya menyusun status kerusakan tanah dengan metode skoring frekuensi relatif (SFR), yaitu perbandingan jumlah sampel tanah yang tergolong rusak dari parameter (fisika, kimia, biologi, kedalaman, batuan dan permeabilitas) terhadap semua sampel atau titik pengamatan. Selanjutnya setiap parameter yang telah diskor dijumlahkan, dilakukan pengkategorian status kerusakan tanah, khusunya untuk lahan kering disajikan dalam tabel 2.

Kriteria kerusakan lahan kering meliputi parameterparameter: ketebalan solum, kebatuan permukaan, komposisi fraksi, berat isi, porositas total, derajat pelulusan air, ph tanah, daya hantar listrik, nilai redoks, jumlah mikroba tanah. Secara rinci disajikan dalam Tabel 3.

\section{Pengumpulan Data di Lapangan}

Pengumpulan data lapangan meliputi pengambilan contoh tanah untuk dianalisa laboratorium yang meliputi parameter yang tersaji dalam table 2, dan pengupulan data untuk mengetahui jumlah biomassa.

\section{Pengukuran Biomassa Tumbuhan}

Pengumpulan data untuk mengetahui jumlah biomassa dengan melakukan pengukuran langsung di lapangan. Lokasi pengambilan contoh ditentukan berdadarkan ketinngian dpl di lokasi yang telah ditentukan. Teknik pengambilan contoh yang digunakan adalah pengambilan contoh didasarkan kebutuhan penelitian (purposive sampling).

\section{HASIL DAN PEMBAHASAN}

\section{Evaluasi Status Kerusakan Tanah}

Berdasarkan hasil pengamatan lapangan yang disajikan dalam Tabel 1, dan hasil analisis tanah di laboratorium, selanjutnya setiap parameter dilakukan evaluasi status kerusakan lahan dengan cara membandingkan terhadap kriteria kerusakan tanah untuk menetapkan skor frekuensi relative (SFR) dan status kerusakan tanag setiap parameter tanah di wilayah tujuh kecamatan seperti disajikan dalam tabel 4, 5, 6, 7, 8, 9 dan 10 .

Berdasarkan hasil penilaian SFR diperoleh 1 dan 2, untuk kecamatan Kuripan dan Tiris skornya 1, maka status kerusakan tanah adalah Rusak Ringan (R.I) dengan faktor pembatas permeabilitas (p), komposisi fraksi pasir dan kolid (f) dan redoks (r). Faktor pembatas permeabilitas (p) dan redoks (r) ditemukan di wilayah kecamatan Kuripan 
melebihi ambang batas. Sedangkan factor pembatas komposisi fraksi pasir dan kolid (f) dan permeabilitas (p) ditemukan di kecamatan Tiris melebihi ambang batas. Skor SFR untuk kecamatan Sukapura, Sumber, Lumbang, Krucil dan Gading diperoleh 2, maka status kerusakan tanahnya Rusak Sedang (R.II). Faktor pembatas komposisi fraksi pasir dan koloid (f) melebihi ambang batas berdasarkan kriteria kerusakan tanah ditemukan di 5 (lima) kecamatan tersebut. Faktor pembatas lain seperti kebatuan permukaan (b), Berat Isi (b), Porositas Total (v), Permeabilitas (p) dan redoks (r) yang melebihi ambang batas. Faktor pembatas yang bersifat permanen seperti komposisi fraksi pasir dan koloid (f) sulit untuk diperbaiki, sedangkan parameter yang lain masih dapat diperbaiki dengan cara pemberian bahan organik berupa kompos, kotoran hewan atau sisa tanaman.Berdasarkan pengamatan lapangan, penggunaan lahan di tujuh lokasi bervariasi, penggunaan lahan untuk tanaman pangan, tanaman buah-buahan, tanaman sayuran, dan tanaman perkebunan. Hasil produksi tanaman diatas merupakan sumber biomasa yang diambil keluar lahan yang dapat menyebabkan degradasi lahan, bahkan dapat menyebabkan lahan kritis.

Produksi biomasa di masing-masing kecamatan disajikan dalam tabel 11, dimana adanya hubungan antara produksi biomasa dengan kerusakan lahan. Kecamatan Kuripan dan Tiris dengan klasifikasi rusak ringan, dengan produksi biomasa 10.896 ton ha ${ }^{-1}$ dan 14.836 ton $^{-1}$. yaitu Sumber, Krucil, Gading, Sukapura dan Lumbang yang dikategorikan rusak sedang, dimana produksi biomasa berturut turut 70.838 ton $\mathrm{ha}^{-1}, 54.855$ ton $\mathrm{ha}^{-1}, 40.514$ ton ha1, dan 27.995 ton $\mathrm{ha}^{-1}$. Produksi biomasa lebih besar dibandingkan dengan kecamatan Tiris dan Kuripan. Semakin besar produksi biomasa yang diambil sebagai hasil panen dari lahan tersebut tanpa ada upaya mengembalikan lagi bahan organic kedalam lahan tersebut, akan menyebabkan lahan tersebut mengalami degradasi lahan, yang berakibat terjadi kerusakan lahan.

Tabel 1. Karakteristik umum lahan di 7 (tujuh) Kecamatan

\begin{tabular}{|c|c|c|c|c|c|c|c|c|c|}
\hline $\mathrm{Kec}$ & Jenis Tanah & $\begin{array}{l}\text { Elevasi } \\
\text { (mdpl) }\end{array}$ & $\begin{array}{l}\text { Sawah } \\
\text { (ha) }\end{array}$ & Tegal (ha) & $\begin{array}{l}\text { Hutan } \\
\text { (ha) }\end{array}$ & $\begin{array}{l}\text { Non } \\
\text { Hutan } \\
\text { (ha) }\end{array}$ & Relief & $\begin{array}{l}\text { Lereng } \\
(\%)\end{array}$ & Drainase \\
\hline Gading & $\begin{array}{l}\text { Non Kalsik, } \\
\text { Litosol, } \\
\text { Andosol, } \\
\text { Mediteran }\end{array}$ & $70-800$ & $\begin{array}{l}3,362 . \\
0\end{array}$ & $8,964.3$ & 5508.5 & 148,7 & $\begin{array}{l}\text { Datar- } \\
\text { Bergelombang }\end{array}$ & 7 & $\begin{array}{l}\text { agak } \\
\text { terhambat } \\
\text { - cepat }\end{array}$ \\
\hline Krucil & $\begin{array}{l}\text { Litosol, Non } \\
\text { Kalsik }\end{array}$ & $500-1000$ & $\begin{array}{l}1,502 . \\
0\end{array}$ & $15,823.1$ & $9,405.9$ & 913.2 & $\begin{array}{l}\text { Bergelombang- } \\
\text { berbukit }\end{array}$ & 40 & $\begin{array}{l}\text { Agak } \\
\text { Cepat }\end{array}$ \\
\hline Tiris & $\begin{array}{l}\text { Non Kalsik, } \\
\text { Andosol, } \\
\text { Litosol }\end{array}$ & $81-1000$ & 568.0 & $14,636.6$ & 4865.7 & 817.4 & $\begin{array}{l}\text { Berombak- } \\
\text { bergelombang }\end{array}$ & 25 & $\begin{array}{l}\text { Agak } \\
\text { terhambat } \\
\text { - sedang }\end{array}$ \\
\hline Lumbang & $\begin{array}{l}\text { Mediteran, } \\
\text { Litosol, Non } \\
\text { Calsik }\end{array}$ & $169-1224$ & 735.0 & 8536.0 & 3849.0 & 146.7 & $\begin{array}{l}\text { Bergelombang- } \\
\text { berbukit }\end{array}$ & 38 & Sedang \\
\hline Sukapura & $\begin{array}{l}\text { Litosol, } \\
\text { Andosol, } \\
\text { Mediteran }\end{array}$ & $650-1800$ & 20.0 & $10,188.5$ & 3948.5 & $\begin{array}{l}1668 . \\
5\end{array}$ & $\begin{array}{l}\text { Bergelombang- } \\
\text { berbukit }\end{array}$ & 45 & $\begin{array}{l}\text { Sedang - } \\
\text { Agak } \\
\text { Cepat }\end{array}$ \\
\hline Kuripan & $\begin{array}{l}\text { Latosol, } \\
\text { Mediteran, } \\
\text { Litosol } \\
\end{array}$ & $250-900$ & 785.7 & $6,815.4$ & 2456.0 & 118.3 & $\begin{array}{l}\text { Berombak- } \\
\text { bergelombang }\end{array}$ & 25 & $\begin{array}{l}\text { Terhamba } \\
\mathrm{t} \text { - sedang }\end{array}$ \\
\hline Sumber & $\begin{array}{l}\text { Litosol, } \\
\text { Latosol }\end{array}$ & $800-1800$ & 171.6 & $14,016.6$ & 7783.0 & 433.9 & $\begin{array}{l}\text { Bergelombang- } \\
\text { berbukit }\end{array}$ & 40 & $\begin{array}{l}\text { Sedang - } \\
\text { Agak } \\
\text { Cepat }\end{array}$ \\
\hline
\end{tabular}

Tabel 2. Status kerusakan tanah berdasarkan nilai akumulasi skor kerusakan tanah

\begin{tabular}{cll}
\hline Simbol & Kelas Status Kerusakan Tanah & Nilai Akumulasi Skor Kerusakan Tanah Lahan Kering \\
\hline N & Tidak rusak & 0 \\
R.I & Rusak ringan & $1-14$ \\
R.II & Rusak sedang & $15-24$ \\
R.III & Rusak berat & $25-34$ \\
R.IV & Rusak sangat berat & $35-40$ \\
\hline
\end{tabular}


Tabel. 3. Evaluasi kerusakan tanah di lahan kering

\begin{tabular}{lll}
\hline No. & Parameter & Ambang Kritis \\
\hline 1 & Ketebalan Solum & $<20 \mathrm{~cm}$ \\
2 & Kebatuan Permukaan & $>40 \%$ \\
3 & Komposisi Fraksi & $<18 \%$ koloid; \\
& & $>80 \%$ pasir kuarsitik \\
4 & Berat isi & $>1,4 \mathrm{~g} / \mathrm{cm} 3$ \\
5 & Porositas Total & $<30 \% ; 70 \%$ \\
6 & Derajat Pelulusan Air & $<0,7 \mathrm{~cm} / \mathrm{jam} ;$ \\
7 & pH (H2O) 1:2,5 & $<4,5 ;>8,5$ \\
8 & Daya Hantar Listrik/ DHL & $>4,0 \mathrm{mS} / \mathrm{cm}$ \\
9 & Potensial Redoks & $<200 \mathrm{mV}$ \\
10 & Jumlah Mikrobia & $<102 \mathrm{cfu} / \mathrm{g}$ tanah \\
& & \\
\hline
\end{tabular}

Tabel 4. Evaluasi status tiap parameter kerusakan tanah di Kecamatan Sukapura

\begin{tabular}{|c|c|c|c|c|c|}
\hline \multirow{2}{*}{ No. } & \multirow{2}{*}{ Parameter } & \multirow{2}{*}{ Ambang Kritis } & \multirow{2}{*}{ Hasil Pengamatan } & \multicolumn{2}{|c|}{ Status } \\
\hline & & & & Rusak & Baik \\
\hline 1 & Ketebalan Solum (s) & $<20 \mathrm{~cm}$ & $>50 \mathrm{~cm}$ & - & $\mathbf{r}$ \\
\hline 2 & Kebatuan Permukaan (b) & $>40 \%$ & $45 \%$ & $\mathbf{r}$ & - \\
\hline 3 & Komposisi Fraksi (f) & $\begin{array}{l}<18 \% \text { koloid; } \\
>80 \% \text { pasir kuarsitik }\end{array}$ & $5,69 \%$ & $\mathbf{r}$ & - \\
\hline 4 & Berat isi (d) & $>1,4 \mathrm{~g} / \mathrm{cm} 3$ & $1,3 \mathrm{~g} / \mathrm{cm}^{3}$ & - & $\mathbf{r}$ \\
\hline 5 & Porositas Total (v) & $<30 \% ;>70 \%$ & $61,81 \%$ & - & $\mathbf{r}$ \\
\hline 6 & Derajat Pelulusan Air (p) & $<0,7 \mathrm{~cm} / \mathrm{jam}$ & $8,63 \mathrm{~cm} / \mathrm{jam}$ & $\mathbf{r}$ & \\
\hline 7 & $\mathrm{pH}(\mathrm{H} 2 \mathrm{O}) \quad 1: 2,5$ (a) & $<\hat{4}, \hat{5} ;>8,5$ & 6,83 & - & $\mathbf{r}$ \\
\hline 8 & Daya Hantar Listrik/DHL(e) & $>4,0 \mathrm{mS} / \mathrm{cm}$ & $1,0 \mathrm{mS} / \mathrm{cm}$ & - & $\mathbf{r}$ \\
\hline 9 & Potensial Redoks (r) & $<200 \mathrm{mV}$ & $194,5 \mathrm{mV}$ & - & $\mathbf{r}$ \\
\hline \multirow[t]{5}{*}{10} & Jumlah Mikrobia (m) & $<102 \mathrm{cfu} / \mathrm{g}$ tanah & $\begin{array}{l}\text { Bakteri }>300 \times 10^{7} \\
\text { Jamur } 3 \times 10^{7}\end{array}$ & - & $\mathbf{r}$ \\
\hline & Jumlah & & & 3 & 7 \\
\hline & FR $(\%):$ & & & \multicolumn{2}{|c|}{$3 / 10 \times 100 \%=30$} \\
\hline & SFR & & & & 2 \\
\hline & SKT (Status Kerusakan Tanah) & & & \multicolumn{2}{|c|}{ Rusak Sedang } \\
\hline
\end{tabular}


Tabel 5. Evaluasi status tiap parameter kerusakan tanah di Kecamatan Sumber

\begin{tabular}{|c|c|c|c|c|c|}
\hline \multirow[b]{2}{*}{ No } & \multirow[b]{2}{*}{ Parameter } & \multirow[b]{2}{*}{ Ambang Kritis } & \multirow[b]{2}{*}{ Hasil Pengamatan } & \multicolumn{2}{|c|}{ Status } \\
\hline & & & & Rusak & Baik \\
\hline 1 & Ketebalan Solum (s) & $<20 \mathrm{~cm}$ & $>60 \mathrm{~cm}$ & - & $\mathbf{r}$ \\
\hline 2 & Kebatuan Permukaan (b) & $>40 \%$ & $<30 \%$ & - & $\mathbf{r}$ \\
\hline 3 & Komposisi Fraksi (f) & $\begin{array}{l}<18 \% \text { koloid; } \\
>\quad 80 \% \text { pasir } \\
\text { kuarsitik }\end{array}$ & $14 \%$ koloid & $\mathbf{r}$ & - \\
\hline 4 & Berat isi (d) & $>1,4 \mathrm{~g} / \mathrm{cm} 3$ & $1,43 \mathrm{~g} / \mathrm{cm}^{3}$ & $\mathbf{r}$ & - \\
\hline 5 & Porositas Total (v) & $<30 \% ;>70 \%$ & $50,09 \%$ & & $\mathbf{r}$ \\
\hline 6 & Derajat Pelulusan Air (p) & $<0,7 \mathrm{~cm} / \mathrm{jam}$ & $8,32 \mathrm{~cm} / \mathrm{jam}$ & $\mathbf{r}$ & - \\
\hline 7 & $\mathrm{pH}(\mathrm{H} 2 \mathrm{O}) \quad 1: 2,5(\mathrm{a})$ & $<\hat{4}, \hat{5} ;>\ddot{8}, 5$ & 6,25 & - & $\mathbf{r}$ \\
\hline 8 & Daya Hantar Listrik/DHL(e) & $>4,0 \mathrm{mS} / \mathrm{cm}$ & $3,80 \mathrm{mS} / \mathrm{cm}$ & - & $\mathbf{r}$ \\
\hline 9 & Potensial Redoks (r) & $<200 \mathrm{mV}$ & $268 \mathrm{mV}$ & $\mathbf{r}$ & - \\
\hline 10 & Jumlah Mikrobia (m) & $<102 \mathrm{cfu} / \mathrm{g}$ tanah & $\begin{array}{l}\text { Bakteri }>300 \times 10^{7} \\
\text { Jamur } 3 \times 10^{7}\end{array}$ & - & $\mathbf{r}$ \\
\hline & Jumlah & & & 4 & 6 \\
\hline & $\mathrm{FR}(\%)$ & & & $4 / 10 \times 1$ & \\
\hline & SFR & & & 2 & \\
\hline & SKT (Status Kerusakan Tanah) & & & Rusal & \\
\hline
\end{tabular}

Tabel 6. Evaluasi status tiap parameter kerusakan tanah di Kecamatan Kuripan

\begin{tabular}{|c|c|c|c|c|c|}
\hline \multirow[b]{2}{*}{ No } & \multirow[b]{2}{*}{ Parameter } & \multirow[b]{2}{*}{ Ambang Kritis } & \multirow{2}{*}{ Hasil Pengamatan } & \multicolumn{2}{|c|}{ Status } \\
\hline & & & & Rusak & Baik \\
\hline 1 & Ketebalan Solum (s) & $<20 \mathrm{~cm}$ & $>60 \mathrm{~cm}$ & - & $\mathbf{r}$ \\
\hline 2 & Kebatuan Permukaan (b) & $>40 \%$ & $<30 \%$ & - & $\mathbf{r}$ \\
\hline 3 & Komposisi Fraksi (f) & $\begin{array}{l}<18 \% \text { koloid; } \\
>80 \% \text { pasir kuarsitik }\end{array}$ & $\begin{array}{l}71 \% \text { koloid } \\
4 \% \text { pasir }\end{array}$ & - & $\mathbf{r}$ \\
\hline 4 & Berat isi (d) & $>1,4 \mathrm{~g} / \mathrm{cm} 3$ & $1,16 \mathrm{~g} / \mathrm{cm}^{3}$ & - & $\mathbf{r}$ \\
\hline 5 & Porositas Total (v) & $<30 \% ;>70 \%$ & $44,87 \%$ & - & $\mathbf{r}$ \\
\hline 6 & Derajat Pelulusan Air (p) & $<0,7 \mathrm{~cm} / \mathrm{jam}$ & $0,45 \mathrm{~cm} / \mathrm{jam}$ & $\mathbf{r}$ & - \\
\hline 7 & $\mathrm{pH}(\mathrm{H} 2 \mathrm{O}) \quad 1: 2,5$ (a) & $<4,5 ;>8,5$ & 5,55 & - & $\mathbf{r}$ \\
\hline 8 & Daya Hantar Listrik/DHL(e) & $>4,0 \mathrm{mS} / \mathrm{cm}$ & $3,92 \mathrm{mS} / \mathrm{cm}$ & - & $\mathbf{r}$ \\
\hline 9 & Potensial Redoks (r) & $<200 \mathrm{mV}$ & $266,00 \mathrm{mV}$ & $\mathbf{r}$ & - \\
\hline \multirow[t]{5}{*}{10} & Jumlah Mikrobia (m) & $<102 \mathrm{cfu} / \mathrm{g}$ tanah & $\begin{array}{l}\text { Bakteri }>300 \times 10^{7} \\
\text { Jamur } 3 \times 10^{7}\end{array}$ & - & $\mathbf{r}$ \\
\hline & Jumlah & & & 2 & 8 \\
\hline & $\mathrm{FR}(\%)$ & & & \multicolumn{2}{|c|}{$2 / 10 \times 100 \%=20$} \\
\hline & SFR & & & \multicolumn{2}{|l|}{1} \\
\hline & SKT (Status Kerusakan Tanah) & & & \multicolumn{2}{|c|}{ Rusak Ringan } \\
\hline
\end{tabular}


Tabel 7. Evaluasi status tiap parameter kerusakan tanah di Kecamatan Lumbang

\begin{tabular}{|c|c|c|c|c|c|}
\hline \multirow[b]{2}{*}{ No. } & \multirow[b]{2}{*}{ Parameter } & \multirow[b]{2}{*}{ Ambang Kritis } & \multirow{2}{*}{ Hasil Pengamatan } & \multicolumn{2}{|c|}{ Status } \\
\hline & & & & Rusak & Baik \\
\hline 1 & Ketebalan Solum (s) & $<20 \mathrm{~cm}$ & $>90 \mathrm{~cm}$ & - & $\mathbf{v}$ \\
\hline 2 & Kebatuan Permukaan (b) & $>40 \%$ & $45 \%$ & $\mathbf{r}$ & - \\
\hline 3 & Komposisi Fraksi (f) & $\begin{array}{l}<18 \% \text { koloid; } \\
>80 \% \text { pasir kuarsitik }\end{array}$ & $16,54 \%$ & $\mathbf{r}$ & - \\
\hline 4 & Berat isi (d) & $>1,4 \mathrm{~g} / \mathrm{cm} 3$ & $1,26 \mathrm{~g} / \mathrm{cm}^{3}$ & - & $\mathbf{r}$ \\
\hline 5 & Porositas Total (v) & $<30 \% ;>70 \%$ & $46,74 \%$ & - & $\mathbf{v}$ \\
\hline 6 & Derajat Pelulusan Air (p) & $\begin{array}{l}<0,7 \mathrm{~cm} / \mathrm{jam} \\
>8,0 \mathrm{~cm} / \mathrm{jam}\end{array}$ & $0,58 \mathrm{~cm} / \mathrm{jam}$ & $\mathbf{r}$ & - \\
\hline 7 & $\mathrm{pH}(\mathrm{H} 2 \mathrm{O}) \quad 1: 2,5$ (a) & $<4,5 ;>8,5$ & 6,43 & - & $\mathbf{r}$ \\
\hline 8 & Daya Hantar Listrik/DHL(e) & $>4,0 \mathrm{mS} / \mathrm{cm}$ & $0,51 \mathrm{mS} / \mathrm{cm}$ & - & $\mathbf{r}$ \\
\hline 9 & Potensial Redoks (r) & $<200 \mathrm{mV}$ & $115,21 \mathrm{mV}$ & - & $\mathbf{r}$ \\
\hline \multirow[t]{5}{*}{10} & Jumlah Mikrobia (m) & $<102 \mathrm{cfu} / \mathrm{g}$ tanah & $\begin{array}{l}\text { Bakteri }>300 \times 10^{77} \\
\text { Jamur } 2 \times 10^{7}\end{array}$ & - & $\mathbf{r}$ \\
\hline & Jumlah & & & 3 & 7 \\
\hline & $\mathrm{FR}(\%)$ & & & $3 / 10 \times 1$ & \\
\hline & SFR & & & 2 & \\
\hline & SKT (Status Kerusakan Tanah) & & & Rusak & \\
\hline
\end{tabular}

Tabel 8. Evaluasi status tiap parameter kerusakan tanah di Kecamatan Krucil

\begin{tabular}{|c|c|c|c|c|c|}
\hline \multirow[b]{2}{*}{ No. } & \multirow[b]{2}{*}{ Parameter } & \multirow[b]{2}{*}{ Ambang Kritis } & \multirow{2}{*}{ Hasil Pengamatan } & \multicolumn{2}{|c|}{ Status } \\
\hline & & & & Rusak & Baik \\
\hline 1 & Ketebalan Solum (s) & $<20 \mathrm{~cm}$ & $>50 \mathrm{~cm}$ & - & $\mathbf{r}$ \\
\hline 2 & Kebatuan Permukaan (b) & $>40 \%$ & $45 \%$ & $\mathbf{r}$ & - \\
\hline 3 & Komposisi Fraksi (f) & $\begin{array}{l}<18 \% \text { koloid; } \\
>80 \% \text { pasir kuarsitik }\end{array}$ & $13 \%$ (koloit) & $\mathbf{r}$ & - \\
\hline 4 & Berat isi (d) & $>1,4 \mathrm{~g} / \mathrm{cm} 3$ & $1,09 \mathrm{~g} / \mathrm{cm}^{3}$ & - & $\mathbf{r}$ \\
\hline 5 & Porositas Total (v) & $<30 \% ;>70 \%$ & $49,74 \%$ & - & $\mathbf{r}$ \\
\hline 6 & Derajat Pelulusan Air (p) & $\begin{array}{l}<0,7 \mathrm{~cm} / \mathrm{jam} \\
>8.0 \mathrm{~cm} / \mathrm{iam}\end{array}$ & $0,64 \mathrm{~cm} / \mathrm{jam}$ & $\mathbf{r}$ & - \\
\hline 7 & $\mathrm{pH}(\mathrm{H} 2 \mathrm{O}) \quad 1: 2,5$ (a) & $<4,5 ;>8,5$ & 5,49 & - & $\mathbf{r}$ \\
\hline 8 & Daya Hantar Listrik/DHL(e) & $>4,0 \mathrm{mS} / \mathrm{cm}$ & $3,10 \mathrm{mS} / \mathrm{cm}$ & - & $\mathbf{r}$ \\
\hline 9 & Potensial Redoks (r) & $<200 \mathrm{mV}$ & $88 \mathrm{mV}$ & $\mathbf{r}$ & - \\
\hline \multirow[t]{5}{*}{10} & Jumlah Mikrobia (m) & $<102 \mathrm{cfu} / \mathrm{g}$ tanah & $\begin{array}{l}\text { Bakteri }>300 \times 10^{7} \\
\text { Jamur } 2 \times 10^{7}\end{array}$ & - & $\mathbf{r}$ \\
\hline & Jumlah & & & 4 & 6 \\
\hline & $\mathrm{FR}(\%)$ & & & \multicolumn{2}{|c|}{$4 / 10 \times 100 \%=40$} \\
\hline & SFR & & & \multicolumn{2}{|l|}{2} \\
\hline & \multicolumn{3}{|l|}{ SKT (Status Kerusakan Tanah) } & \multicolumn{2}{|c|}{ Rusak sedang } \\
\hline
\end{tabular}


Tabel 9. Evaluasi status tiap parameter kerusakan tanah di Kecamatan Tiris

\begin{tabular}{|c|c|c|c|c|c|}
\hline \multirow[b]{2}{*}{ No. } & \multirow[b]{2}{*}{ Parameter } & \multirow[b]{2}{*}{ Ambang Kritis } & \multirow{2}{*}{$\begin{array}{l}\text { Hasil } \\
\text { Pengamatan }\end{array}$} & \multicolumn{2}{|c|}{ Status } \\
\hline & & & & Rusak & Baik \\
\hline 1 & Ketebalan Solum (s) & $<20 \mathrm{~cm}$ & $>70 \mathrm{~cm}$ & - & $r$ \\
\hline 2 & Kebatuan Permukaan (b) & $>40 \%$ & $<30 \%$ & - & $\mathbf{r}$ \\
\hline 3 & Komposisi Fraksi (f) & $\begin{array}{l}<18 \% \text { koloid; } \\
>80 \% \text { pasir kuarsitik }\end{array}$ & $15 \%$ & $\mathbf{r}$ & - \\
\hline 4 & Berat isi (d) & $>1,4 \mathrm{~g} / \mathrm{cm} 3$ & $1,1 \mathrm{~g} / \mathrm{cm}^{3}$ & - & $\mathbf{r}$ \\
\hline 5 & Porositas Total (v) & $<30 \% ;>70 \%$ & $51 \%$ & - & $\mathbf{r}$ \\
\hline 6 & Derajat Pelulusan Air(p) & $<0,7 \mathrm{~cm} / \mathrm{jam}$ & $0,41 \mathrm{~cm} / \mathrm{jam}$ & $\mathbf{r}$ & - \\
\hline 7 & $\mathrm{pH}(\mathrm{H} 2 \mathrm{O}) 1: 2,5$ (a) & $<4,5 ;>8,5$ & 5,86 & - & $\mathbf{r}$ \\
\hline 8 & Daya Hantar Listrik/DHL(e) & $>4,0 \mathrm{mS} / \mathrm{cm}$ & $3,45 \mathrm{mS} / \mathrm{cm}$ & - & $\mathbf{r}$ \\
\hline 9 & Potensial Redoks (r) & $<200 \mathrm{mV}$ & $82 \mathrm{mV}$ & - & $\mathbf{r}$ \\
\hline 10 & Jumlah Mikrobia (m) & $<102 \mathrm{cfu} / \mathrm{g}$ tanah & $\begin{array}{l}\text { Bakteri }>300 \times 10^{7} \\
\text { Jamur } 3 \times 10^{7}\end{array}$ & - & $\mathbf{r}$ \\
\hline & Jumlah & & & 2 & 8 \\
\hline & FR $(\%)$ & & & $2 / 10 \times 1$ & \\
\hline & SFR & & & 1 & \\
\hline & SKT (Status Kerusakan Tanah) & & & Rusak & \\
\hline
\end{tabular}

Tabel 10. Evaluasi Status Tiap Parameter Kerusakan Tanah di Kecamatan Gading

\begin{tabular}{|c|c|c|c|c|c|}
\hline \multirow{2}{*}{ No } & \multirow{2}{*}{ Parameter } & \multirow{2}{*}{ Ambang Kritis } & \multirow{2}{*}{$\begin{array}{l}\text { Hasil } \\
\text { Pengamatan }\end{array}$} & \multicolumn{2}{|c|}{ Status } \\
\hline & & & & Rusak & Baik \\
\hline 1 & Ketebalan Solum (s) & $<20 \mathrm{~cm}$ & $>90 \mathrm{~cm}$ & - & $\mathbf{v}$ \\
\hline 2 & Kebatuan Permukaan(b) & $>40 \%$ & $<30 \%$ & - & $\mathbf{v}$ \\
\hline 3 & Komposisi Fraksi (f) & $\begin{array}{l}<18 \% \text { koloid; } \\
>80 \% \text { pasir kuarsitik }\end{array}$ & $9,67 \%$ & $\mathbf{r}$ & - \\
\hline 4 & Berat isi (d) & $>1,4 \mathrm{~g} / \mathrm{cm} 3$ & $1,23 \mathrm{~g} / \mathrm{cm}^{3}$ & - & $\mathbf{r}$ \\
\hline 5 & Porositas Total (v) & $<30 \% ;>70 \%$ & $48,84 \%$ & - & $\mathbf{r}$ \\
\hline 6 & Derajat Pelulusan Air(p) & $\begin{array}{l}<0,7 \mathrm{~cm} / \mathrm{jam} \\
>8,0 \mathrm{~cm} / \mathrm{jam}\end{array}$ & $8,49 \mathrm{~cm} / \mathrm{jam}$ & $\mathbf{r}$ & - \\
\hline 7 & $\mathrm{pH}(\mathrm{H} 2 \mathrm{O}) \quad 1: 2,5$ (a) & $<4,5 ;>8,5$ & 6,53 & - & $\mathbf{r}$ \\
\hline 8 & Daya Hantar Listrik/DHL(e) & $>4,0 \mathrm{mS} / \mathrm{cm}$ & $0,52 \mathrm{mS} / \mathrm{cm}$ & - & $\mathbf{r}$ \\
\hline 9 & Potensial Redoks (r) & $<200 \mathrm{mV}$ & $225,6 \mathrm{mV}$ & $\mathbf{r}$ & - \\
\hline \multirow[t]{5}{*}{10} & Jumlah Mikrobia (m) & $<102 \mathrm{cfu} / \mathrm{g}$ tanah & $\begin{array}{l}\text { Bakteri }>300 \times 10^{7} \\
\text { Jamur } 2 \times 10^{7}\end{array}$ & - & $\mathbf{r}$ \\
\hline & Jumlah & & & 3 & 7 \\
\hline & $\mathrm{FR}(\%)$ & & & $3 / 10 \times 1$ & \\
\hline & SFR & & & 2 & \\
\hline & SKT (Status Kerusakan Tanah) & & & Rusak & \\
\hline
\end{tabular}


Tabel 11. Status Kerusakan Tanah dan Skor Frekuansi Relatif, Tiap-Tiap Kecamatan

\begin{tabular}{llcccc}
\hline No. & Kecamatan & Skor Frekuaensi Relatif (SFR) & Status Kerusakan Tanah & Simbol & Produksi $^{\text {Biomasa (ton ha }}{ }^{-1}$ ) \\
\hline 1 & Sukapura & 2 & Rusak sedang & R.II-b,f,a & 23.171 \\
2 & Sumber & 2 & Rusak sedang & R.II-f,d,v,r & 70.838 \\
3 & Kuripan & 1 & Rusak ringan & R.I-p,r & 10.896 \\
4 & Lumbang & 2 & Rusak sedang & R.II-b,f,p & 27.995 \\
5 & Krucil & 2 & Rusak sedang & R.II-b,f,p,r & 54.855 \\
6 & Tiris & 1 & Rusak ringan & R.I-f,p & 14.836 \\
7 & Gading & 2 & Rusak sedang & R.II-f,p,r & 40.514 \\
\hline
\end{tabular}

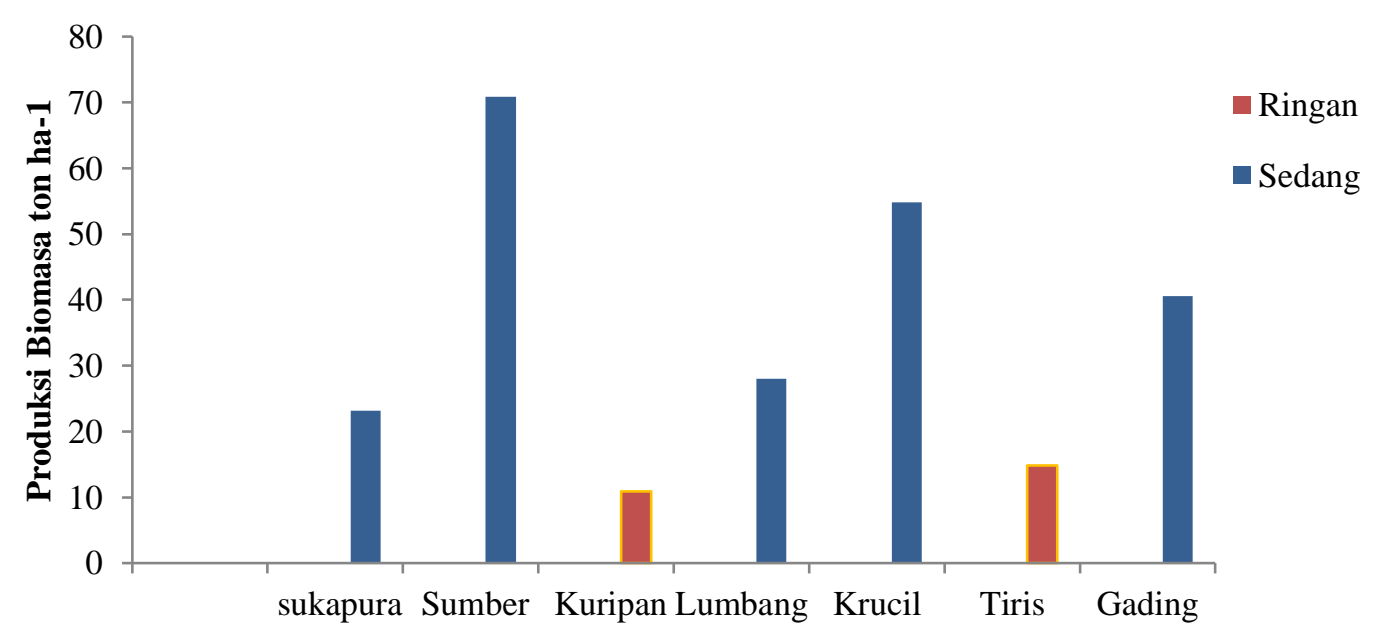

Gambar 1. Hubungan produksi biomasa dengan status kerusakan tanah

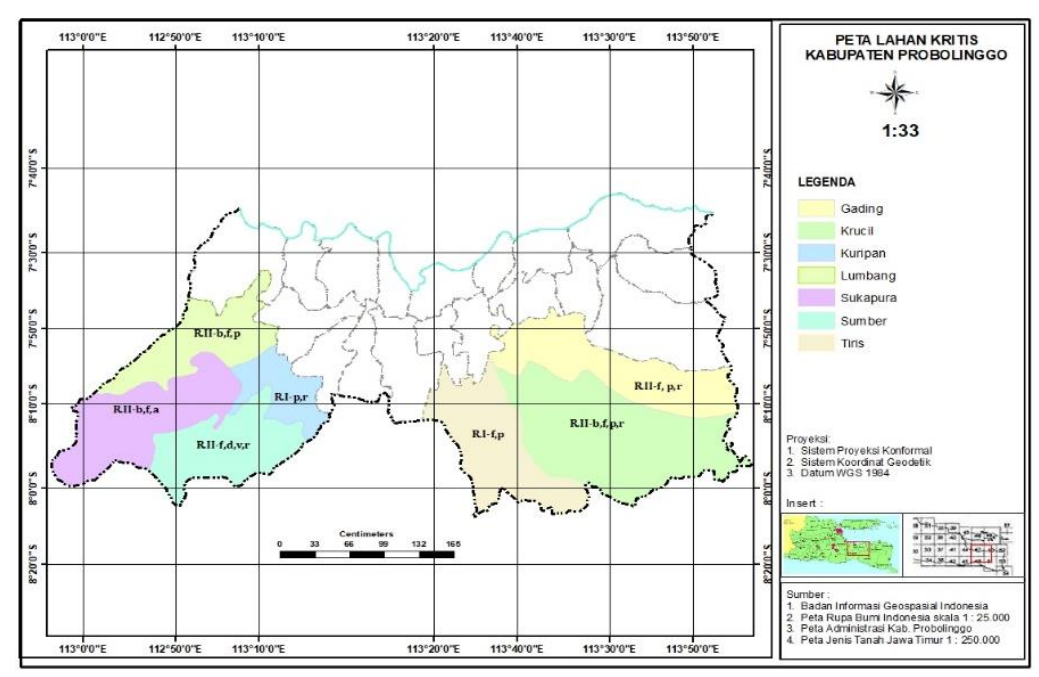

Gambar 2. Peta status kerusakan tanah di tujuh kecamatan 


\section{KESIMPULAN}

Berdasarkan hasil dan evaluasi status kerusakan tanah dapat disimpulkan bahwa: Status kerusan tanah pada daerah yang dikaji tergolong rusak ringan yaitu di wilayah kecamatan Tiris dan Kuripan dengan factor pembatas masingmasing Komposisi fraksi pasir dan koloid (f), permeabilitas, dan redoks (r). Sedangkan lima kecamatan lainnya yaitu Sumber, Sukapura, Lumbang, Krucil, dan Gading tergolong rusak sedang. Faktor pembatasnya Komposisi fraksi pasir dan koloid (f), (b), berat Isi (b), porositas total (v), permeabilitas (p) dan redoks (r) yang melebihi/dibawah ambang batas. Faktor pembatas komposisi fraksi bersifat permanen sehingga sulit diperbaikai atau dirubah untuk menjadi lebih baik, sedangkan faktor pembatas permeabilitas dibawah ambang batas dapat diperbaiki menjadi lebih baik dengan penambahan bahan organik. sehingga tidak menjadi pembatas.

\section{DAFTAR PUSTAKA}

BPS Kabupaten Probolinggo. (2017). Kabupaten Probolinggo Dalam Angka 2017. Probolinggo: BPS Kabupaten Probolinggo.

Dariah, A., Rachman, A., \& Kurnia, U. (2004). Erosi dan degradasi lahan kering di Indonesia.

Departemen Kehutanan. (2009). Peraturan Menteri Kehutanan Republik Indonesia Nomor : P. 32/Menhut - II/2009 tentang Tata Cara Penyusunan Rencana Teknik Rehabilitasi hutan dan lahan Daerah Aliran Sungai (RTkRHL-DAS). Jakarta (ID): Dephut.

Didu, M. S. (2001). Analisis posisi dan peran lembaga serta kebijakan dalam proses pembentukan lahan kritis. Jurnal Teknologi Lingkungan, 2(1): 93-105. https://journal.ipb.ac.id/index.php/jtanah

Fahmi, A., \& Hanudin, E. (2008). Pengaruh Kondisi Redoks terhadap Stabilitas Kompleks Organik-besi pada Tanah Sulfat Masam. Jurnal Tanah dan Lingkungan, 8(1), 49-55.

Hanafiah, K. A. (2005). Dasar - Dasar Ilmu Tanah. Divisi Buku Perguruan Tinggi PT. Raja Grafindo Persada. Jakarta.

Indrihastuti, D., Murtilaksono, K., \& Tjahjono, B. (2016). Analisis lahan kritis dan arahan rehabilitasi lahan dalam pengembangan wilayah Kabupaten Kendal Jawa Tengah. TATALOKA, 18(3), 141-156.

Iswahyudi, I. (2017). Pengelolaan lahan kritis hutan lindung bukit batabuh berkelanjutan. Jurnal Penelitian Agrosamudra, 4(1), 91-99.

Kusumaningtyas, A. S., Cahyono, P., Sudarto, S., \& Suntari, R. (2017). Pengaruh tinggi muka air terhadap pH, Eh, $\mathrm{Fe}$, Aldd, Mn dan P terlarut pada tanaman nanas klon GP3 di ultisol. Jurnal Tanah dan Sumberdaya Lahan, 2(1), 103-109.

Rosyada, M., Prasetyo, Y., \& Haniah, H. (2015). Penentuan tingkat lahan kritis menggunakan metode pembobotan dan algoritma Ndvi (Studi Kasus: Sub DAS Garang Hulu). Jurnal Geodesi Undip, 4(1), 85-94.

Peraturan Pemerintah. (2000). Peraturan Pemerintah Nomor 150 tahun 2000 tentang Pengendalian Kerusakan Tanah untuk Produksi Biomasa.

Peraturan Menteri Negara Lingkungkungan Hidup. (2008). Peraturan Menteri Negara Lingkungan Hidup, No. 20 tahun 2008, tentang Peraturan Teknis Standar Pelayanan Minimal (SPM) Bidang Lingkungan Hidup Daerah Provinsi dan Kabupaten/Kota.

Peraturan Menteri Negara Lingkungkungan Hidup. (2009). Peraturan Menteri Negara Lingkungan Hidup Nomor 17 tahun 2009 Tentang Pedoman Penentuan Daya Dukung Lingkungan Hidup Dalam Penataan Ruang, Jakarta.

Peraturan Dirjen Bina Pengelolaan DAS dan Perhutanan Sosial. (2013). Peraturan Dirjen Bina Pengelolaan DAS dan Perhutanan Sosial Nomor P.4/V-SET/2013 tentang Petunjuk Teknis Penyusunan Data Spasial Lahan Kritis.

Peraturan Direktur Jenderal Pengendalian Daerah Aliran Sungai dan Hutan Lindung. (2018). Peraturan Direktur Jenderal Pengendalian Daerah Aliran Sungai dan Hutan Lindung Nomor P.3/Pdashl/Set/Kum.1/7/2018 Tentang Petunjuk Teknis Penyusunan Data Spasial Lahan Kritis.

Yulnafatmawita, Y., Luki, U., \& Yana, A. (2007). Kajian sifat fisika tanah beberapa penggunaan lahan di bukit gajabuih kawasan hutan hujan tropik gunung gadut padang. Jurnal Solum, 4(2), 49-62. 